\title{
STRUKTUR FONOLOGIS NAMA ORANG MINANGKABAU
}

\author{
Reniwati, Noviatri, dan Rona Almos
}

\begin{abstract}
Abstrak
Nama Minangkabau memiliki ciri khas tersendiri yang dapat dikenali melalui struktur fonologis . Artikel ini menjelaskan jumlah panjang kata nama Minangkabau, jumlah suku kata, dan sifat dari masing-masing suku kata. Ada tiga metode dan teknik penelitian yang digunakan dalam penelitian ini: menyediakan data, analisis data, dan penyajian hasil analisis. Berdasarkan jumlah, struktur fonologi nama Minangkabau memiliki dua kecenderungan. Pertama, orang-orang tua lebih dari 43 tahun cenderung terdiri dari 1 ( satu ) nama kata. Kedua, orang berusia kurang dari 44 tahun cenderung terdiri dari nama dua kata. Berdasarkan jumlah suku kata, namanama Minangkabau juga memiliki dua kecenderungan. Pertama, orang berusia lebih dari 43 tahun nama cenderung terdiri dari tiga ( 3 ) suku kata diikuti oleh nama yang terdiri dari 2 ( dua ) suku kata. Kedua, nama orang-orang Minangkabau di bawah 44 tahun lebih bervariasi, ada terdiri dari 2 sampai 5 suku kata , beberapa dari mereka yang terdiri dari 6 sampai 7 suku kata. Selain itu, nama lama tidak ditemukan Minangkabau yang terdiri dari satu suku kata dan melebihi 7 suku kata. Akhirnya, berdasarkan sifat, ada dua sifat suku kata dalam nama Minangkabau yang suku tertutup dan suku kata terbuka.
\end{abstract}

Kata kunci: nama, Minangkabau, struktur fonologis, suku kata

\begin{abstract}
Name of the Minangkabaunese has its own characteristics which can be recognized through the phonological structure. This article describes the number of word length Minangkabau name, the number of syllables, and the nature of each syllable of the name. There are three methods and research techniques used in this study: providing data, data analysis, and presentation of analysis results. Based on the number, the phonological structures of the Minangkabaunese names have two tendencies. First, people over 43 years old tend to consist of 1 (one) word name. In contrast, less than 44 years old tend to consist of two words name. Based on the number of syllables, the Minangkabaunese names also have two tendencies. First, over 43 years old the name tends to consist of three (3) syllables followed by a name consisting of 2 (two) syllables. The name of the Minangkabau people under 44 years are more varied, there consist of 2 to 5 syllables, some of them consisting of 6 to 7 syllables. Furthermore, the long name is not found Minangkabau consisting of one syllable and exceeds 7 syllables. Finally, based on the nature, there are two properties of syllables in the Minangkabaunese name which are closed syllables and open syllables.
\end{abstract}


Keywords: name, Minangkabau, phonological structure, syllable.

\section{PENGANTAR}

Melalui nama diri, orang bisa memprediksi asal-usul daerah atau suku seseorang. Orang Batak, misalnya dapat dikenali dari namanya. Nama diri mereka diikuti oleh nama marga, misal Sitompul, Nasution, atau Siregar. Nama orang Sunda ditandai dengan pengulangan suku kata pertama. Nama orang Jawa antara lain ditandainya dengan adanya bunyi /o/ di belakang namanya atau bunyi /y/ di awal nama mereka. Lalu, bagaimana dengan nama orang Minangkabau? Apakah juga memiliki kekhasan seperti nama orang dari daerah atau suku lain yang sebagian telah disebut di atas?

Nama orang Minangkabau tidak sama seperti nama orang Batak. Mereka tidak biasa mencantumkan nama suku di belakang nama diri. Dalam artikel ini akan dibahas kekhasan nama orang Minangkabau dari sudut bentuk bahasa, tepatnya pada unsur bunyi.

Dalam kerangka pemecahan permasalahan, Sudaryanto (1998) menyebutkan bahwa ada tiga metode dan teknik penelitian yang dapat digunakan, yaitu 1) metode dan teknik penyediaan data, 2) metode dan teknik analisis data, dan 3) metode dan teknik penyajian hasil analisis data. Dalam penyediaan data penelitian, metode yang digunakan adalah metode cakap dengan teknik dasar yang dipakai adalah teknik pancing. Teknik lanjutannya adalah teknik cakap semuka (TCS), teknik catat, dan teknik rekam.

Populasi penelititan ini adalah seluruh nama orang Minangkabau di Sumatera Barat, kecuali Kabupaten Mentawai. Adapun sampelnya adalah nama-nama orang Minangkabau yang berumur di atas 39 tahun di Kabupaten Padang Pariaman dan Kabupaten 50 Kota. Dari nama orang yang berumur demikian diharapkan diperoleh model nama orang Minangkabau dulu atau lama. Masing-masing sampel penelitian diambil enam (6) kanagarian 'desa'. Keenam lokasi ini dipandang sudah mewakali nagari yang ada di dua kabupaten ini.

Metode yang digunakan dalam analisis data adalah metode padan dan metode agih. Untuk metode padan digunakan metode padan referansial yang alat penentunya adalah kenyataan yang ditunjuk oleh bahasa bersangkutan, dalam hal ini masing-masing nama orang Minangkabau akan dicarikan referennya atau acuannya. Karena nama orang Minangkabau ada yang berasal dari bahasa Arab, maka diperlukan pula metode padan ortografis yang alat penentunya adalah tulisan/ huruf yang menandai masing-masing nama. Teknik dasar yang digunakan adalah teknik pilah unsur penentu (PUP) dengan pirantinya daya pilah yang bersifat mental. Teknik lanjutannya adalah teknik hubung banding membedakan yang berguna untuk membedakan stuktur nama yang satu dengan nama lainnya.

Dalam metode agih juga digunakan teknik dasar dan teknik lanjutan. Teknik 
dasar metode agih adalah teknik bagi unsur langsung (TBUL). Teknik lanjutan yang digunakan adalah teknik perluas dan teknik sisip. Teknik perluas digunakan untuk menjelaskan aspek kemaknaan dari masing-masing nama.

Dalam menyajikan hasil analisis data digunakan metode penyajian formal dan informal. Dalam penyajian formal, hasil analisis data disajikan dengan menggunakan seperangkat simbol dan lambang. Sementara dalam penyajian informal, hasil analisis disajikan dengan uraian biasa, dalam bentuk kata-kata dan kalimat

Bahasa adalah sistem bunyi (Kridalaksana, 1993) dan bunyi ini merupakan satuan bahasa terkecil. Di atas bunyi ada satuan bahasa lagi, yaitu kata. Nama diri (proper name) termasuk dalam tataran kata. Di dalam kategorisasi kata yang dibuat oleh Kridalaksana (2005), nama termasuk ke dalam kelas kata pronomina.

Sebagai sebuah kata, nama diri bisa terdiri atas satu atau lebih suku kata. Suku kata merupakan satu pulsa minimal dari aktivitas inisiator yang dibatasi dengan penundaan sesaat (Catford, 1990:178-179). Dari definisi ini, penanda suku kata adalah adanya hentian pelafalan sejenak. Berdasarkan pendekatan fonologis, suku kata tersusun atas inti suku kata (sillabic nucleus), biasanya vokal, dan segmensegmen nonsilabik yang menjadi tetangganya (Yusuf, 1998:53). Dari pernyataan ini dapat dikatakan bahwa suku kata ditandai dengan vokal. Oleh karena nama terdiri atas suku kata, maka pada nama tersebut pastilah ada unsur vokalnya, termasuk pada nama pendek yang menjadi nama panggilan.

Berpijak pada pengertian bahasa sebagai sistem bunyi yang arbitrer (Kridalaksana, 1993), maka wajar apabila nama orang Minangkabau memiliki kekhasan dalam struktur fonologisnya. Fonotaktik merupakan sebuah bidang kajian yang membahas struktur fonologis ini. Menurut Fudge dalam N.E. Colinge (1990: 57), fonotaktik adalah sebuah studi tentang segala kemungkinan pengkombinasian fonem pada suatu bahasa. Berbeda dengan Fudge, Catford (1990:187) memasukan fonotaktik ke dalam kajian Fonologi sama halnya dengan persoalan bunyi, fonem, dan suku kata. Menurutnya, Fonologi adalah studi yang membicarakan penataan bunyi-bunyi bahasa ke dalam sistem serta bagaimana pula bunyi tersebut digunakan dalam bahasa.

Nama diri bukan sekedar susunan huruf atau bunyi. Dari nama, orang tahu, asal-usul keluarga, suku, atau kebangsaannya. Melalui nama, orang tahu jenis kelamin pemilik nama. Melalui nama pula, orang tahu sejarah dan budaya masyarakat si pemilik nama tersebut. Seperti yang dikatakan oleh Thomas dan Wareing (2007:227-237), nama adalah identitas personal dan kelompok sosial. Nama sekaligus adalah pembentuk keduanya.

\section{Struktur Fonologis}

Struktur fonologis nama panjang dapat ditinjau dari sudut jumlah kata, suku kata, dan sifat suku kata tersebut.

\section{Jumlah Kata}


Dari analisis jumlah kata pada nama panjang terlihat ada dua kecenderungan. Kecenderungan itu berkait dengan periode tahun kelahiran. Kecenderungan pertama ialah bahwa nama orang yang berumur 43 tahun ke atas cenderung terdiri atas 1 (satu) kata. Kecenderungan kedua merupakan kebalikan dari kecenderungan pertama. Kecenderungannya ialah bahwa nama orang yang berumur di bawah 44 tahun cenderung terdiri atas dua kata.

$\begin{array}{ll}\text { Umur }+\mathbf{4 3} & \text { Umur }-\mathbf{4 4} \\ \text { Animar } & \text { Rino Putra } \\ \text { Nurdin } & \text { Dicky Irawan } \\ \text { Rosma } & \text { Harmen Sahladi }\end{array}$

\section{Jumlah Suku Kata}

Hasil analisis nama panjang dari sudut jumlah suku kata didapati kecenderungan yang sama seperti pada sudut jumlah kata dalam nama panjang. Kecenderungan pertama ialah bahwa nama orang yang berumur 43 tahun ke atas cenderung terdiri atas 3 suku kata dan diikuti oleh nama yang terdiri atas 2 suku kata. Kecenderungan kedua ialah bahwa jumlah suku kata nama orang yang berumur 44 tahun ke bawah cenderung lebih bervariasi. Dengan kata lain tidak ada jumlah suku kata tertentu yang mendominasi seperti pada kecenderungan yang pertama. Jumlah suku kata pada kecenderungan ini hampir merata. Jumlah suku katanya antara 2 sampai 5 suku kata. Ada satu nama yang terdiri atas 6 dan 7 suku kata. Kecenderungan ketiga ialah bahwa tidak ada nama yang terdiri atas 1 suku kata dan lebih dari 7 suku kata kecuali kalau nama diri tersebut diikuti gelar.

\author{
2 Suku Kata \\ Katik /ka.ti?/ \\ Katun $/ \mathrm{ka} / \mathrm{tun} /$ \\ Munah /mu.nah/
}

\section{Suku Kata}

Ramiah /ra.mi.ah/

Jasmani /jas.ma.ni/

Nurjani /nur.ja.ni/

\author{
4 Suku Kata \\ Restu Rida/res.tu.ri.da/ \\ Ermiati /er.mi.a.ti/ \\ Ramayulis /ra.ma.yu.lis/
}

\section{Suku Kata}

Nuraini Basyar /nur.ai.ni.ba.sar/

Purnamawati /pur.na.ma.wa.ti/

Elvi Nurita /el.vi.nu.ri.ta/

\section{6/7 Suku Kata}

Ramadhani Latessa /ra.ma.da.ni.la.te.sa/

Ingelia Retrimerti /i.ne.li.a.ret.ri.mer.ti/

Miftahul Muhajid /mif.ta.hu.mu.ha.jit/

\section{Sifat Suku Kata}


Berdasarkan sifat suku kata, nama panjang menunjukkan dua sifat suku kata, yaitu suku kata tertutup dan suku kata terbuka. Suku kata terbuka ialah suku kata yang berakhir dengan vocal, sedangkan suku kata tertutup ialah suku kata yang berakhir dengan konsonan. Dari dua sifat suku kata ini, nama juga menunjukkan kecenderungan. Kecenderungan itu juga berkait dengan umur dari pemilik nama tersebut.

Kecenderungan pertama ialah bahwa nama yang bersuku kata tertutup cenderung terdapat pada nama orang yang berumur tua, yaitu berumur lebih dari 59 tahun. Kecenderungan kedua ialah kebalikan dari kecenderungan pertama. Nama orang yang bersuku terbuka cenderung terdapat pada nama orang yang berumur muda, yaitu berumur kurang dari 53 tahun. Makin muda umur dari pemilik nama makin banyak yang namanya bersifat suku kata terbuka.

\section{Suku Kata Terbuka}

Syafridawati

Teti Yoseva

Ruswand $i$

\section{Suku Kata Tertutup}

Maryam

Marnis

Muharman

\section{Bunyi pada Nama}

Bahasa Minangkabau memiliki 20 bunyi konsonan. Konsonan itu adalah /p/,

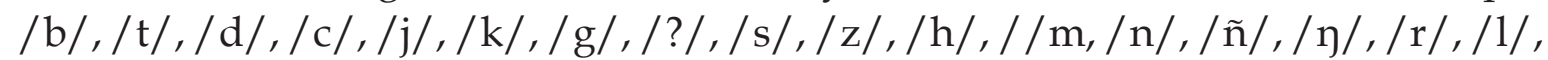
$/ \mathrm{w} /$, dan $/ \mathrm{y} /$. Di samping semua bunyi tersebut masih ada dua bunyi lain yang ada pada nama, yaitu bunyi / ̌s/ dan /x/.

Tabel Distribusi Bunyi Konsonan pada Nama

\begin{tabular}{|c|c|c|c|c|}
\hline No. & Bunyi & Awal & Tengah & Akhir \\
\hline 1 & $/ \mathrm{p} /$ & purnamawati & ade saputra & - \\
\hline 2 & $/ \mathrm{b} /$ & buyuay juo & lombo & - \\
\hline 3 & $/ \mathrm{t} /$ & taher & aton & wat (nama panggilan) \\
\hline 4 & $/ \mathrm{d} /$ & darwis & suardi & - \\
\hline 5 & $/ \mathrm{c} /$ & cun (nama pendek) & $\begin{array}{c}\text { lanci? (panggilan } \\
\text { kesayangan) }\end{array}$ & - \\
\hline 6 & $/ \mathrm{j} /$ & jarian & bujay (julukan) & - \\
\hline 7 & $/ \mathrm{k} /$ & kardan & jakardi & - \\
\hline 8 & $/ \mathrm{g} /$ & guswendi & rahmat gumilan & kati? \\
\hline 9 & $/ ? /$ & $? ? ? ?$ & ????? & idris \\
\hline 10 & $/ \mathrm{s} /$ & sari nun & rosminarti & abuzar \\
\hline 11 & $/ \mathrm{z} /$ & zainal & jahan & asnah \\
\hline 12 & $/ \mathrm{h} /$ & husni warni & &
\end{tabular}




\begin{tabular}{|c|c|c|c|c|}
\hline 13 & $/ \mathrm{m} /$ & misnar & yulimar & maryam \\
\hline 14 & $/ \mathrm{n} /$ & nelyani & jusnani & imun \\
\hline 15 & $/ \tilde{\mathrm{n}} /$ & - & koña & - \\
\hline 16 & $/ \mathrm{y} /$ & dulen & o $\eta$ ki manday & buyua $\eta$ \\
\hline 17 & $/ \mathrm{r} /$ & rimbun & marhamah & munir \\
\hline 18 & $/ 1 /$ & lalama & $\begin{array}{c}\text { zulvita nelwati /zulpita } \\
\text { nelwati/ }\end{array}$ & jefrizal /jeprizal/ \\
\hline 19 & $/ \mathrm{w} /$ & wendri donal & midawati & - \\
\hline 20 & $/ \mathrm{y} /$ & $y$ eniti & ramayulis & - \\
\hline 21 & $\mid \check{s} /$ & $\begin{array}{c}- \\
\text { šafridawati /saprida/ }\end{array}$ & - & - \\
\hline 22 & $/ \mathrm{x} /$ & xasnidar /kasnidar/ & $\begin{array}{c}- \\
\text { muhamad xaidir/muhamat } \\
\text { kaidir/ }\end{array}$ & - \\
\hline 23 & $/ \mathrm{f} /$ & fitriani /pitriani/ & jefrizal /jeprizal/ & $\begin{array}{c}- \\
\text { muhammad yusuf / } \\
\text { muhamat yusup/ }\end{array}$ \\
\hline 24 & $/ \mathrm{v} /$ & - & - & - \\
\hline
\end{tabular}

Dari tabel distribusi diatas tampak bahwa banyakjuga bunyi yang berdistribusi tidak lengkap. Distribusinya yang paling banyak adalah pada posisi di akhir kata.

Dalam sistem bunyi bahasa Minangkabau, bunyi /p/, /b/, t/, /d/, /c/, /j/, /g/, /s/, /z/, / $\tilde{\mathrm{n}} /, / \mathrm{r} /$, dan /1/ tidak muncul di akhir kata. Sebagian dari sistem ini tidak berlaku pada nama. Huruf d pada nama cenderung dilafalkan sebagai / $\mathrm{t} /$. Huruf s, 1, r, pada nama juga cenderung bertahan sebagai bunyi /s/, /1/, dan /r/. Bunyi /c/, /j/, /g/, dan / ñ/, seperti halnya pada sistem bunyi, tidak muncul di akhir nama. Meskipun ada nama yang disesuaikan dengan bunyi-bunyi bahasa Minangkabau, jumlah nama yang demikian tidaklah banyak. Bunyi-bunyi tersebut cenderung lebih banyak muncul pada nama julukan dan kemudian diikuti oleh nama kesayangan. Sementara pada nama panjang dan pendek, bunyi-bunyi tersebut cenderung tidak muncul. Nama julukan dan nama kesayangan itu ialah buyua (nama panjang berbeda), mih dari Misbah, upia? (nama panjang berbeda), dan gadih dari Gadis. Data juga menunjukkan bahwa ada daerah yang tidak mengucapkan bunyi seperti demikian. Bunyinya sama seperti nama panjang: Rosminarti tetap dipanggil ros (nama kesayangan dan julukan), Yusnidar dipanggil yus (nama kesayangan dan julukan, ada juga daerah yang menggunakan yuh), Guswandi dipanggil oguh (nama julukan) dan igus (nama kesayangan). Data juga menunjukan perbedaan dalam panggilan kesayangan dan julukan, misal Narwilis dipanggil ilih (nama julukan) dan lis (nama pendek). Meskipun perbedaan itu dilatarbelakangi oleh perbedaan dialek atau subdialek, namun sebagiannya menunjukkan adanya 
kebertahanan bunyi-bunyi bahasa Melayu terutama pada nama-nama pendek (seperti pada nama panjang).

Bunyi / w/ dan /y/ ada dalam bahasa Minangkabau. Berdasarkan data yang terkumpul, kedua bunyi ini juga cenderung tidak muncul di akhir kata.

Bunyi-bunyi /z/, /š/, /f/, /v/,dan / x/ merupakan bunyi pinjaman. Kecuali bunyi / z/ yang cenderung bertahan dan diucapkan sebagaimana bunyi tersebut, bunyi /š/ cenderung diucapkan sebagai /s/, dan bunyi /f/ dan /v/ cenderung diucapkan sebagai /p/. Bunyi terakhir, /x/ cenderung pula diucapkan berbeda, yaitu sebagai /k/.

Dari segi vokal, bahasa Minangkabau memiliki 5 vokal. Semua vokal tersebut terdapat pada semua nama yang menjadi data penelitian ini. Vokal itu ialah /a/, /e/,/o/, /u/, dan /i/.

Tabel Distribusi Bunyi Vokal pada Nama

\begin{tabular}{|c|c|c|c|c|}
\hline No. & Bunyi & Awal & Tengah & Akhir \\
\hline 1 & /a/ & $a$ snan adil & sudarma putra & sellyt $a$ \\
\hline 2 & /e/ & erni & jefrizal & mañe \\
\hline 3 & $/ \mathrm{o} /$ & oๆki mandai & $10 \mathrm{mbo}$ & subarso \\
\hline 4 & $/ \mathrm{u} /$ & $u$ man & rusiah & $\begin{array}{c}\text { unc } u \text { (panggilan } \\
\text { kesayangan) }\end{array}$ \\
\hline 5 & $/ \mathrm{i} /$ & indrawati & jamilis & suryat $i$ \\
\hline
\end{tabular}

Dari tabel di atas tampak bahwa vokal tersebar pada semua posisi dengan catatan bahwa sedikit nama yang mengandung vokal /e/ di akhir nama tersebut. Vokal /o/ dan / u/ juga jarang dijumpai di posisi awal dan akhir nama.

Jenis bunyi lain, yaitu diftong juga terdapat pada nama. Sebagai sebuah sistem bunyi, diftong pada nama juga tidak memiliki distribusi lengkap. Selain itu, jumlah nama yang mengandung diftong pun sedikit. Berikut contoh data yang mengandung diftong.

$\begin{array}{cc}\text { Diftong } & \text { Nama } \\ \text { /ia/ } & \text { upia? } \\ \text { /ua/ } & \text { buyuan } \\ \text { /ui/ } & \text { aluih }\end{array}$

Ketiga contoh ini merupakan nama kesayangan dan julukan.

\section{Kekhasan Nama Perempuan dan Laki-Laki}

Struktur fonologis nama dibagi atas nama perempuan dan laki-laki. Berikut ini adalah uraiannya.

\section{Nama Perempuan}


Dari data yang terkumpul, nama perempuan Minangkabau cenderung mengandung unsur $\{(\mathrm{n})(\mathrm{i}) \mathrm{ar}\},\{\mathrm{mar}\},\{$ dar $\}$, dan $\{$ wati\}. Unsur ini terletak di akhir nama. Unsur yang terakhir merupakan sufik bahasa Sanskerta yang merupakan pemarkah nama perempuan. Di samping ketiga unsur ini, banyak juga nama perempuan mengandung kata nur. Kata ini merupakan kata bahasa Arab dan berarti cahaya. Demikianlah unsur-unsur yang membentuk kekhasan nama perempuan. Contoh nama-nama itu ialah sebagai berikut.

$\begin{array}{cc}\text { Yusdaniar } & \text { Syamsiar } \\ \text { Janimar } & \text { Yusnimar } \\ \text { Yulimar } & \text { Yusnidar } \\ \text { Midawati } & \text { Purnamawati } \\ \text { Nur Hasanah. } & \text { Nurjani }\end{array}$

Kekhasan nama perempuan lainnya terletak pada vokal /i/. Vokal ini cenderung ada dan menjadi salah satu bunyi yang membentuk nama perempuan.

\section{Nama Laki-Laki}

Seperti nama perempuan, nama laki-laki Minangkabau juga memiliki kekhasan. Kekhasan itu terlihat pada bunyi - $\{d i n\}$ dan -(z)al. Contoh nama yang memperlihatkan pola ini antara lain ialah sebagai berikut.

$\begin{array}{cc}\text { Syamsuddin } & \text { Nurdin } \\ \text { Jefrizal } & \text { Zainal }\end{array}$

Unsur - din merupakan kata bahasa Arab yang bermakna agama. Sementara unsur -(z)al merupakan kreasi orang Minangkabau. Dua nama terakhir, yaitu jefrizal berasal dari kata jafri yang bermakna bunga kuning dan zainal berasal dari kata zain yang bermakna cantik.

Selain kekhasan di atas, laki-laki juga memiliki kekhasan yang lain, yaitu vokal /a/. Vokal ini cenderung ada pada nama mereka.

\section{Penutup}

Dari analisis data terhadap nama-nama orang Minangkabau didapat beberapa kesimpulan. Dari segi struktur fonologis nama panjang dapat ditinjau dari sudut jumlah kata, suku kata, dan sifat suku kata tersebut. Dari jumlah kata ada dua kecenderungan. Kecenderungan pertama ialah bahwa nama orang yang berumur 43 tahun ke atas cenderung terdiri atas 1 (satu) kata. Kecenderungan kedua ialah bahwa nama orang yang berumur di bawah 44 tahun cenderung terdiri atas dua 
kata.

Dari segi suku kata terdapat dua kecenderungan juga. Kecenderungan pertama ialah bahwa nama orang yang berumur 43 tahun ke atas cenderung terdiri atas 3 suku kata dan diikuti oleh nama yang terdiri atas 2 suku kata. Kecenderungan kedua ialah bahwa jumlah suku kata nama orang yang berumur 44 tahun ke bawah cenderung lebih bervariasi. Dari segi sifat suku kata, nama panjang menunjukkan dua sifat suku kata, yaitu suku kata tertutup dan suku kata terbuka.

Kajian mengenainama diri orang Minangkabau perlu dilanjutkan. Pembicaraan dalam artikel baru menyangkut masalah bunyi yang membentuk nama itu. Perlu kajian lanjutan mengenai asal-usul bentuk nama, latar belakang pemberian nama, dan motivasi yang terkandung pada nama tersebut. Dari kajian ini nantinya juga akan diketahui asal-usul nama orang Minangkabau.

\section{DAFTAR PUSTAKA}

Almos, Rona. 2010. “Makna Nama Diri pada Masyarakat Minangkabau”. Laporan Penelitian Dana DIPA Unand tahun 2010.

Baikoeni, Elfitra. 2009.“Nama Orang Minangkabau: Unik, Fleksibel, dan "Aneh". www.scribd.com/doc/, 10 Mei 2009.

Bright, William. 1971. Sosiolinguistic. Paris: The Hague.

Catford, J.C. 1990. A Practical Introduction to Phonetics. New York: Oxford University Press.

Crystal, David. 1987. The Cambridge Encyclopedia of Languge. Cambridge: Cambridge University Press.

Fasold, Ralph. 1990. The Sociolinguistic of Language. Cambridge Centre: Basil Block Well Inc

file/ / D:/pendidikkan/berkarakter.htm. "Pendidikan di Indonesia Belum Berhasil".

file/ / / D:/ ahmad-farhan/hamid/pembangunan/karakter/dimulai/dari / keluarga.htm. "Pembangun Karakter Dimulai dari Keluarga"

guario.blogspot.com/2004/10. "Kalau Orang Minang Kasih Nama". 10 Mei 2009.

Koentjaraningrat. 1990. Beberapa Pokok Antropologi Sosial. Jakarta: Dian Rakyat.

Kridalaksana, Harimurti. 1993. Kamus Linguistik. Cet. III. Jakarta : Gramedia .1989. Pembentukan Kata Dalam Bahasa Indonesia. Jakarta: Gramedia. .1986. Kelas Kata dalam Bahasa Indonesia. Jakarta : Gramedia.

Lapoliwa, Hans. 1981. 'A Generative Approach to the Phonology of Bahasa Indonesia".

Canberra: Pacific Linguistics.

.1982. "Phonological Problem of Loanwords in Bahasa Indonesia". Canberra: Pacific Linguistics. C-75.

Mahsum, 2005. Metode Penelitian Bahasa: Tahapan Strategis Metode dan Tekniknya. Jakarta : PT. Raja Grafindo Persada.

Marnita, Rina. 2000. "Perubahan Sosial Budaya dan Dampaknya terhadap Bahasa Minangkabau". Makalah yang dipresentasikan pada Seminar Linguistik Bahasa dan Perubahan Sosial yang Diselenggarakan oleh MLI Cabang Unand. Padang, Mei 11.

Moussay, Gerard. 1981. La Langue Minangkabau. Association Archipel.

Navis, A.A. 1985. Alam Terkambang Jadi Guru. Jakarta: PT Grafiti Pers.

Noviatri. 1997. “Kaidah Fonotaktik Nama-nama Daerah di Jawa” . Laporan Peneltian Mandiri.

Pusat Pembinaan dan Pengembangan Bahasa. 1993. Tata Bahasa Minangkabau. Jakarta.

Reniwati. 2008. “StrukturFonologis Nama Orang Minangkabau”. Laporan Penelitian DIPA Unand. 
Sudaryanto, 1993. Metode dan Teknik Analisisi Bahasa, Yogyakarta : Duta Wacana. University Press.

,1994. Pemanfaatan Potensi Bahasa. Yogyakarta : Gadjah Mada University Press.

Thomas dan Wareing. 2007. Bahasa, Masyarakat $\mathcal{E}$ Kekuasaan (terjemahan). Yogyakarta:

Pustaka Pelajar.

Yusuf, Suhendra, Drs., M.A. 1998. Fonetik dan Fonologi. Jakarta: PT Gramedia Pustaka Utama. 